\title{
INORGANIC SPECIES IN GROUNDWATER - HEALTH AND REMEDIATION: A GLOBAL OVERVIEW
}

\author{
Jacks $G$. \\ DIv Land \\ Water Resources Eng., KTH, SE-100 44 Stockholm, Sweden
}

\section{INTRODUCTION}

The most problematic species are anions, as adsorption of anions is weaker than adsorption of cations. Adsorption of anions decrease with $\mathrm{pH}$ while the opposite is true for cations like most heavy metals. Anionic, health affecting species are arsenite, fluoride, chromate and nitrate. Common adsorbents are organic matter and ferric hydroxides, the former adsorbing cations and the latter anions.

Arsenic is an old poison that has made a come-back and found to be a health risk in groundwater (Bhattacharya et al. 1997). It is inorganic arsenic which is toxic while organic forms of arsenic methylated species and arsenobetaine, found in sea food and fish is easily excreted by humans. Coastal, reducing aquifers in Bangladesh, West Bengal in India, in the Mekong and Red River deltas in Vietnam carry arsenic causing melanosis which might develop into cancer. Bangladesh is worst affected with 35-70 M people exposed, depending on the permissible limit, WHO:s at $10 \square \mathrm{g} / \mathrm{l}$ or the national at $50 \square \mathrm{g} / \mathrm{l}$. While arsenic is easily removed, filters do not function socially in developing countries - women expected to handle them are too burdened with other tasks (Jakariya et al. 2007). In Bangladesh it has been found that safe aquifers can be identified by sediment colours. Reddish oxidizing sediments carry low arsenic water (Hossain et al. 2014).

Manganese is another redox sensitive element, recently found to have adverse effect on chronically exposed children (Bouchard et al. 2011). The intellectual capacity is lowered even at levels below the WHO:s and Swedish permissible limits. Manganese is an essential element, its uptake is well controlled from food but not from water. This may be due to that the use of deeper anoxic groundwater is a new phenomenon in the history of mankind.

Fluoride protects teeth from caries at levels around $1 \mathrm{mg} / \mathrm{l}$ but has a narrow therapeutic spectrum. Dental fluorosis, mottling of teeths, occurs at $2 \mathrm{mg} / \mathrm{l}$ in warmer climates like in India. At $5 \mathrm{mg} / \mathrm{l}$ the skeleton is affected and at $10 \mathrm{mg} / \mathrm{l}$ crippling is seen (Muralidharan et al. 2011). In skeletal fluorosis fluoride is built into the hydroxyapatite of the skeleton, making it less degradeable for the osteoclasts which results in bone substance accumulation in heavily loaded parts of the skeleton like the vertebra and the knee joints. Fluoride filters do not function well in developing countries. A low capacity requires frequent regeneration. In India water harvesting is found to dilute the fluoride sufficiently to come down to lower levels.

Chromium in the form of chromate is quite mobile. Excessive chromate in groundwater is found in India at metal plating and leather tanning industries at level of several $\mathrm{mg} / \mathrm{l}$.

Uranium is not a health risk due to irradiation but may cause kidney problems. It is rather common in granitic terrains. The uranium species at neutral $\mathrm{pH}$ are anionic or have no charge while uranium is quite mobile.

\section{What can be done?}

Arsenic is mobilized in anoxic aquifers as arsenite into groundwater when it is released from ferric hydroxides which are reduced to ferrous iron releasing the adsorbed arsenic. Arsenic can also be 
mobilized as arsenate under high $\mathrm{pH}$ conditions when aluminium and iron oxides lose their positive charge. Arsenic can be removed by filters, commonly activated alumina but also by ferric compounds like laterite or even ferric hydroxide coated sand. A problem is that the capacity is limited and filters need frequent regeneration.

\section{Extraction Well}

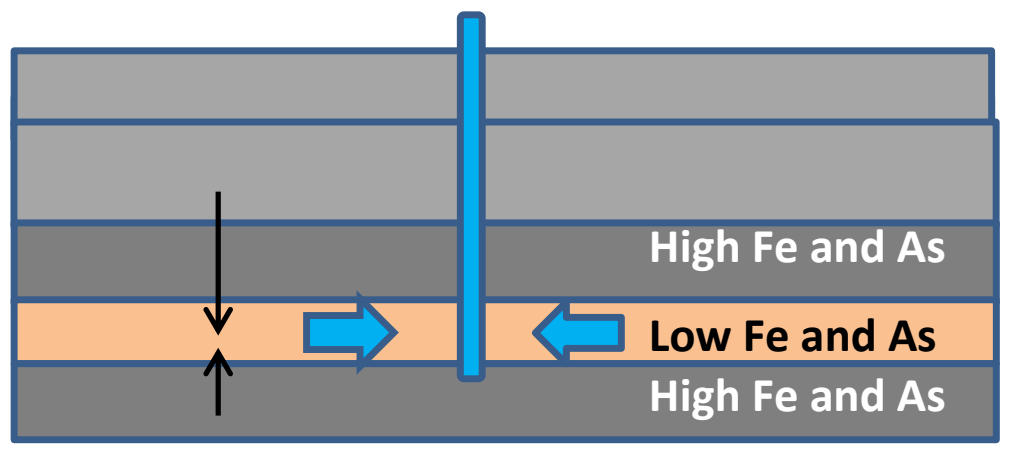

Fig. 1. Sketch figure over sediments in the Bengal delta. Horisontal hydraulic conductivity is about ten times higher than the vertical while crosscontamination risk is small.

In India about $60 \mathrm{M}$ people are exposed to levels above $1.5 \mathrm{mg} / \mathrm{l}$ (Muralidharan et al. 2011), under which exposure dental fluorosis is common. It seems as well to be a growing problem due to increasing alkalinity of soils under which fluoride is mobilized in water of the $\mathrm{Na}-\mathrm{HCO}_{3}$-type (Fig. X). The transformation of groundwater from the $\mathrm{Ca}-\mathrm{HCO}_{3}$ type to $\mathrm{Na}-\mathrm{HCO}_{3}$ to even $\mathrm{Na}-\mathrm{HCO}_{3}-\mathrm{Cl}$ types occurs over distances in the terrain of one to tenths of kilometres (Jacks et al. 2005; Reddy et al. 2010).

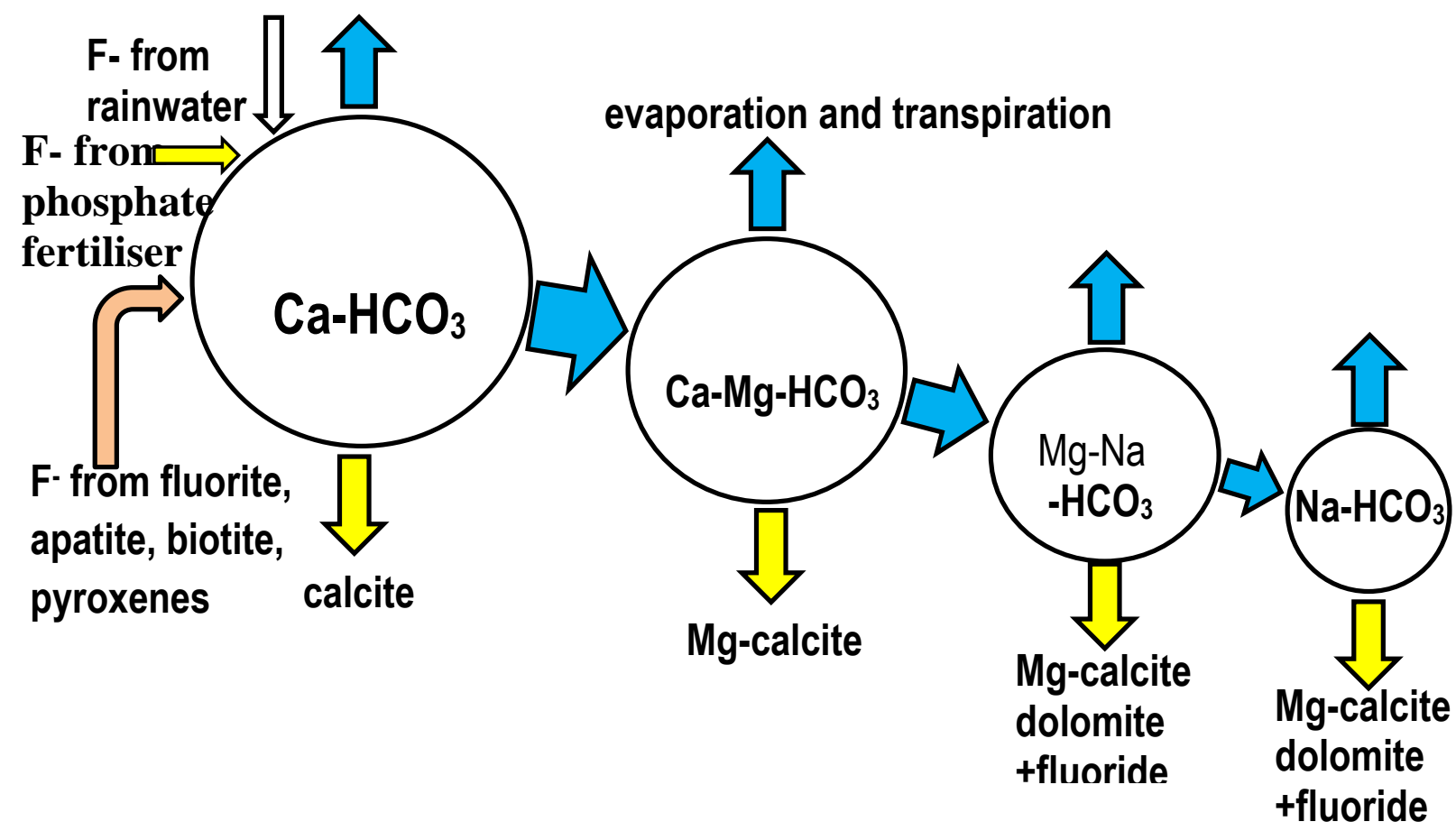




\section{Fig. 2. Conceptual model for the formation of High fluoride groundwater in India.}

The reason for the alkalinisation of soils is irrigation and poor drainage in irrigated areas. In India water harvesting is a mean of decreasing fluoride content in groundwater. Better water use efficiency is needed and new cropping patterns. The much debated System for Rice Intensification (SRI) when rice fields are allowed to dry up between irrigations is saving about $40 \%$ of the water as compaqred to the conventional water logged cultivation (Sungh et al. 2012).

Chromium in the form pf chromate is quite mobile. It is found in groundwater especially in connection to electroplating activities but also released from leather tanning industries. In India these activities are commonly practised. In Ludhiana in Punjab in India $5 \mathrm{mg} / \mathrm{l}$ of chromate was found at $50 \mathrm{~m}$ depth in a sandy aquifer (Chaudhary et al. 2001). In Tamil Nadu there are numerous tanning factories which have polluted groundwater as well as surface water (Vinodhini and Das 2010). Evaporation basins are used to recover the chromium, something that could be practised during the dry season. Reduction of $\mathrm{Cr}(\mathrm{VI})$ to $\mathrm{Cr}(\mathrm{III})$ by reactive organic matter can be used the retain the chromium (Vinodhini and Das 2010; Wilkin et al. 2014).

Uranium in groundwater is commonly found in granitic terrains but also in connection to black shales (Lavergren et al. 2009). The decay rate is slow and it does not constitte a radiation risk but rather a chemical effect on the kidneys (Kurrtio et al. 2002). Uranium in groundwater forms an abundance of complexes (Norrström and Löv 2014). Thus for this reason the removal of uranium by any treatment method requires a knowledge of the species present. What regards another related specie, radon, it can be removed by aeration. Radon is generally lower in dug wells than in drilled wells.

\section{References}

Bhattacharya, P., Chatterjee, D. and Jacks, G. (1997) Occurrence of arsenic contaminated groundwater in alluvial aquifers from Delta Plains, Eastern India. - Options for safe drinking water supply. Int. J. Water Resources Develop. 13: 79-92.

Bouchard, M. F., Sauvé, S., Barbeau, B., Legrand, M., Brodeur, M. E., Bouffard, T., Limoges, E., Bellinger, D. C. and Mergler, D. (2011) Intellectual impairment in school-age children exposed to manganese from drinking water. Environ. Health Perspect. 119: 138-43.

Chaudhary, V., Singh, K. P., Jacks, G. and Bhattacharya, P. (2001) Groundwater contamination at Ludhiana, Punjab, India. Indian Water Works Assoc. 33(3): 251-261.

Hossain, M., Bhattacharya, P., Frape, S. K., Jacks, G., Islam, M.M., Rahman, M. M., von Brömssen, M.,

Hasan, M. A. and Ahmed, K. M. (2014) Sediment color tool for targeting arsenic-safe aquifers for the installation of shallow drinking water tubewells. Sci. Tot. Environ. 493: 615-625.

Jacks, G. Bhattacharya, P, Chaudhary, V. and Singh, K. P. (2005) Controls on the genesis of some high.fluoride groundwaters in India. Appl. Geochem. 20: 221-228.

Jakariya, M., von Brömssen, M., Jacks, G., Chowdhury, A. M. R., Ahmed, K. M. and Bhattacharya, P. (2007). searching for sustainable arsenic mitigation strategy in

Bangladesh: experiences from two upazilas. Int. J. Environ. Poll., v. 31. pp. 415-430.

Kurttio, P., Auvinen, A., Salonen, I., Saha, H., Pekkanen, J., Mäkeläinen, I., Väiyänen, S. B., Penttilä, , I.

M. and Kortelainen, H. (2002) Renal effects of uranium in drinking water. Environ. Health Perspect. 110: 337-342.

Lavergren, U., Åström, M., Falk, H. and Bergbäck, B. (2009) Metal dispersionin an area with natural and processed black shale - Nationwide perspective and comparison with acid sulphate soils. 


\section{Linnaeus ECO-TECH '14}

Kalmar, Sweden, November 24-26, 2014

Appl. Geochem. 24: 359-369.

Muralidharan, D., Rangarajan, R. and Shankar, B. K. (2011). Vicious cycle of fluoride in semi-arid India - a health concern. Current Sci., v. 100(5), pp. 638-640.

Norrström, A-C. and Löv, Å. (2014) Uranium theoretical speciation for drinking water from private d drilled wells in Sweden - Implications for choice of removal method. Appl. Geochem. 53: 148154.

Reddy, D. V., Nagabhushanam, P., Sukhija, B. S., Reddy, A. G. S. and Smedley, P. L. (2010). Fluoride dynamics in the granitic aquifer of the Wailapally watershed. Chem. Geol., v. 269 pp. 278-289.

Sungh, Y. V., Singh, K. K., and Sharma, S. K. (2012) Influence of crop nutrition on grain yield, seed quality and water productivity under two rice cultivation systems. Rice Science 20: 129-138.

Vinodhini, V. and Das, N. (2010) Packed bed column studies on Ct(VI) removal from tannery wastewater by neem dust. Desalination 264: 9-14.

Wilkin , R. T., Acree, S. D., Ross, R. R., Puls R. W., Lee, T. R. and Woods, L. L. (2014)

Fifteenyear assessment of a permeable reactive barrier for treatment of chroate and trochlorethylene in groundwater. Sci. Tot. Environ. 468-469: 186-194. 